\title{
Effect of Arbuscular Mycorrhizal Fungi on Soil Chemical Characteristics in Apple Orchards of Kashmir Himalaya
}

\author{
Misbah Ajaz Malik ${ }^{*}$, M.Y. Zargar ${ }^{1}$, Masrat Maqbool ${ }^{2}$, Bisma Rashid ${ }^{1}$, \\ Z.A. Baba ${ }^{1}$ and Malik Asif ${ }^{1}$ \\ ${ }^{1}$ Division of Basic Sciences and Humanities, ${ }^{2}$ Division of Soil Sciences, Sher e Kashmir \\ University of Agricultural Sciences and Technology of Kashmir-193201, India \\ *Corresponding author
}

\section{A B S T R A C T}

\begin{tabular}{|l|}
\hline Ke y w or d s \\
Chemical parameters, \\
Correlation, AM fungi, \\
Kashmir
\end{tabular}

\section{Introduction}

Arbuscular mycorrhizal fungi (AMF) are geographically ubiquitous and occur over a broad ecological range. They are commonly found in association with numerous plant species including Agricultural and Horticultural crops. Arbuscular mycorrhizal fungi (AMF) of the phylum Glomeromycota are considered to associate with at least 80 per cent of vascular land plants. The association of plants with AMF improves plant establishment, growth and productivity. These fungi are well known to enhance plant nutrient uptake, plant tolerance to drought and abiotic stresses and to protect them against pathogens and nematodes. Additionally, AM fungi stabilize soils and improve soil structure through binding sand grains and aggregate formation.

The root infections by AMF consist of intercellular hyphae and vesicles together with finely branched arbuscules which develop within the host cortical cells. External mycelium attaches to the roots, ramifies into the surrounding cells and produces small vegetative spores and larger resting spores singly or in sporocarps. The plants are responsive to inoculation with mycorrhizal fungi, especially in soils which are low in fertility (Mosse, 1973; Hayman, 1982). 


\section{Material and Methods}

\section{Study area}

District Pulwama is an important part of Kashmir valley with respect to the agricultural perspective and is surrounded by Srinagar in the north, Budgam and Poonch in the west and Anantnag and Shopian in the east and south side. The district is situated between $33^{\circ} 46^{\prime}$ to $33^{\circ} 58^{\prime} \mathrm{N}$ Latitude and $74^{\circ} 45^{\prime}$ to $75^{\circ} 13^{\prime} \mathrm{E}$ longitude with a mean elevation of about 1630 m amsl.

It contributes a total geographical area of $0.109 \mathrm{~m}$ ha out of which $0.02365 \mathrm{~m}$ ha is under agriculture and $0.0412 \mathrm{~m}$ ha under forest cover, rest being used for other purposes. Pulwama soils are shallow to deep, mostly loam to silty loam and silty clay to clay. The wide variations in soil characteristics are mostly associated with slope aspect. The soils are mostly subjected to moderate to severe erosion and have moderate surface stoniness at some places.

\section{Isolation and purification of Arbuscular mycorrhizal spores}

Isolation of AM fungal spores from the rhizospheric soil samples was done by following Wet sieving and decanting method (Gerdemann and Nicolson 1963). The spores were counted under microscope Olympus $\mathrm{CH} 20 \mathrm{i}$ with magnification of $10 \times 40$.). Spore population was then expressed in terms of number of spores per $100 \mathrm{gm}$ of dry soil (Table 1). Clean and intact spores were isolated using a specially designed needle, spores were mounted with PVLG (poly vinyl alcohol+ lactic acid+ glycerol) + Melzer's Reagent and observed under microscope and photographed. Identification of spores up to generic level was based on spore size, spore colour, wall layers and hyphal attachments using the species descriptions provided by
INVAM (http://invam.caf.wvu.edu) and other suitable references (Schenck and Perez, 1990; Morton and Benny, 1990; Almeida and Schenck, 1990; Bentivenga and Morton, 1995; Walker and Vestberg, 1998).

\section{Assessment of AM fungal colonization of isolated spores}

The isolated spores were further purified and mass multiplied on maize. Surface sterilized healthy maize seeds, pre-germinated in Petri plates under aseptic conditions, were sown in polythene bags containing sterilized soil + sand mixture $(1: 2 \mathrm{w} / \mathrm{w})$. These bags were aseptically inoculated with identical AM spores at $5 \mathrm{~cm}$ depth (Jackson, 1973).

The bags were kept in a greenhouse at $25 \pm 3^{\circ} \mathrm{C}$ and irrigated with sterile water. The plants were uprooted after 45 days. The roots were collected, washed with sterile water to remove adhering soil debris and observed for mycorrhizal infection. The infectivity was proved by noticing the presence of hartig net, vesicles, asbuscules or hyphae of endophytes on roots.

For estimating mycorrhizal root colonization, the root samples were collected and washed carefully to remove the adhering debris. The tertiary roots were cut into small pieces of approximately $1 \mathrm{~cm}$ length and subjected to differential staining as described by (Phillips and Hayman, 1970). The estimation of mycorrhizal infection in roots was made by visual observation (Giovannetti and Mosse, 1980). A randomly selected aliquot of stained root segments, suspended in water, was spread in a Petridish viewed under a dissecting microscope at a magnification of 10 and $40 x$. In case of AM colonization, root segments containing vesicles and arbuscules of endophyte and number of mycorrhizal short roots were considered infected as suggested by Beckjord et al., (1984). 
Per cent mycorrhizal infection $=$ Number of infected root segments / Total number of segments examined $\times 100$

The data recorded during the investigation was statistically analyzed with the help of Pearson correlation (Gomez and Gomez, 1984).

\section{Chemical parameters}

The organic carbon, available nitrogen, Available phosphorus and available $\mathrm{K}$ of the soil were estimated by method of Walkey and Black (1934), Alkaline permagnate method (subhaiah and Asija, 1956), olsen's method Olsen et al., (1954) and Flamephotometric method (Jackson, 1958) respectively.

\section{Results and Discussion}

\section{Morphological characterization Arbuscular mycorrhizal spores}

Spore morphology and wall characteristics were considered for the identification of Arbuscular mycorrhizal fungi. Four types of genera viz., Glomus, Acaulospora, Scutellospora and Gigaspora, were recovered and identified. 3 to 6 unidentified spores per gram from all studied locations were tagged as unidentified spores (Table 2). The spore colour of the species of Glomus was of wide range.

It varied from red-brown to almost black or straw to dark orange but most was yellow brown in colour. Spores possessed globose to sub-globose shape, about 40 to $120 \mu \mathrm{m}$ in size. Spore wall consisted of three layers (L1, L2 and L3). Our findings corroborate with those of many other workers (Koske, 1984; Koske and Gemma, 1990). Acaulospora spores were present singly in the soil and develop laterally on the neck of asporiferous saccule. Spores were light orange to yellowish brown (Table 3 and Figures 1, 2, 3 and 4) globose to sub-globose in shape and 150 to $210 \mu \mathrm{m}$ in diameter. These spores were triple layered with L1 which forms the spore surface light yellow to apricot yellow in colour and 0.7 to $2.0 \mu \mathrm{m}$ in thickness. L2 was laminate and light orange to yellowish brown, 6.8 to 7.4 $\mu \mathrm{m}$ in thickness. L3 was laminate, hyaline, 0.8 to $1.6 \mu \mathrm{m}$ in thickness and usually tightly adherent to L2.

Similar observations have been reported by others also (Walker et al., 2007), Sharma et al., (2009). Scutellospora spores were with or without ornamentations. Spores consisted of a bilayered spore wall and two bilayered flexible inner walls.

Thin-walled auxillary cells with smooth to knobby surfaces were produced on hyphae in the soil near the root surface and were also reported by (Schenck and Perez, 1990) and (Morton, 2002). Gigaspora spore wall consisted of a permanent outer layer enclosing a laminate layer, each with different properties that distinguish species (e.g. color, thickness, etc). Our observations corroborate with those of Koske (1987) and Bentivenga and Morton (1995).

There was no evidence of any ectomycorrhizal association with apple roots, and this corroborates with the findings of Greene et al., (1982). Glomus species was common and made up for more than $75 \%$ of total isolates followed by Acaulospora, Gigaspora and Scutellospora.

Dominancy of Glomus in the present study is in agreement with the findings of many other workers (Mridha and Dhar, 2007; Burni et al., 2009; Sharma et al., 2009). The predominance of Glomus spp. under varying soil conditions might be due to the fact that they are widely adaptable to the varied soil conditions and survive in acidic as well as in alkaline soils (Pande and Tarafdar, 2004). 
Root colonization studies of Arbuscular mycorrhizal fungi

In the current study, the AM colonization in the apple roots from Pulwama district varied between 65.87 and $79.78 \%$ (Table 4, Figure 5, 6,7 , and 8). The results are in conformity with the Kandula et al., (2006) who also observed higher colonization in the apple roots and confirmed the ubiquitous nature of AMF spores. The highest root colonization was recorded in response to the inoculation with Glomus spp. (79.78\%) followed by Acaulospora species (79.56\%), Gigaspora species $(73.56 \%)$ and Scutellospora species $(71.23 \%)$. Similar results were reported by some workers Gosal et al., (2003) (Smith and Read, 2008).

Results of the present study indicate that the nutrient contents of the soils played a significant role in occurrence of different species of Arbuscular mycorrhizal fungi and it is evident from the Perusal of the data presented in Table 2 which revealed that AM spore population of district Pulwama was positively and significantly correlated with organic carbon $\left(\mathrm{r}=0.887^{* *}\right)$. The results are in conformity with those of Lipinski et al., (2003) who also reported a significant positive correlation between soil organic carbon and AM spore population.

There was a significant correlation between AM spore population and root colonization $(\mathrm{r}=0.512 *)$ in district Pulwama. Kumar et al., (2013) also found a significant positive correlation between mycorrhizal spores and colonization. Yang et al., (2010) found a positive correlation between and mycorrhizal colonization and spores. These results are also supported by Li et al., (2009). The positive and significant correlation between AM spores and available nitrogen $\left(\mathrm{r}=0.815^{*}\right)$ was found which might be due to the fact that nitrogen and organic carbon are required by micro- organisms for their special requirements and as a result high nitrogen and organic carbon in the soil increased infection and population of AM fungi. Similar results were reported by Venkatrao et al., (1972).

Since the climatic conditions of the study area fall under temperate zone which are conducive to the mycorrhizal development, it is possible that concentration of such propagules may be higher (Akhter, 2005)

Moreover, influence of apple roots through their exudates cannot be ruled out which needs further studies.

\section{Chemical analysis of soil}

\section{Organic carbon}

Perusal of the data presented in Table 5 indicates that organic carbon content of soils of identified villages ranged between 1.68\% (Shiekhar) and $1.96 \%$ (Pinglin) with an average of $1.80 \%$. The organic carbon content of Pinglin soil was significantly more than the soils of other villages except for Rajpora and Shiekhar which was statistically at par. Najar (2002) found that organic carbon content varied from 1.4 to $2.4,0.9$ to 1.8 and 0.5 to 1.2 in the high altitude and valley basin orchard soils of Kashmir. Wani et al., (2010) reported organic carbon content of 1.1 to $2.10 \%$ in the soils of Himalayan region. The variation in the organic carbon content may be due to variation in the application of organic manures and the population of the soil microorganisms. As a food source for soil fauna and flora, soil organic carbon plays an important role in the soil food web by controlling the number and types of soil inhabitants which serve important functions such as nutrient cycling and availability, assisting root growth and plant nutrient uptake, creating burrows and even suppressing crop diseases. These findings are supported by Bulluck et al., (2002). 


\section{Table.1 Mean Spore count per gram of rhizosphere soil of District Pulwama}

\begin{tabular}{|l|}
\hline Villages \\
\hline Rajpura \\
\hline Shadimarg \\
\hline Nikas \\
\hline Drubgam \\
\hline Shiekar \\
\hline Tikkin \\
\hline Sunsomil \\
\hline Pinglin \\
\hline Gungoo \\
\hline Puhoo \\
\hline Mean \\
\hline
\end{tabular}

\begin{tabular}{|c|}
\hline Spore population/g \\
\hline 7 \\
\hline 12 \\
\hline 7 \\
\hline 7 \\
\hline 8 \\
\hline 10 \\
\hline 8 \\
\hline 8 \\
\hline 8 \\
\hline 8.7
\end{tabular}

\section{Table.2 Isolation of Arbuscular mycorrhizal spores from rhizospheric soil of apple from different locations of District Pulwama}

\begin{tabular}{|l|c|c|c|c|c|}
\hline & \multicolumn{5}{|c|}{ Spore count per gram of soil (Identified Genera) } \\
\hline & Acaulospora & Scutellospora & Gigaspora & Glomus & $\begin{array}{c}\text { Unidentified } \\
\text { Genera }\end{array}$ \\
\hline Rajpora & - & - & 1 & 2 & 4 \\
\hline Shadimarg & 2 & - & 3 & 3 & 4 \\
\hline Nikas & 1 & 2 & - & - & 4 \\
\hline Drubgam & - & 1 & 1 & 2 & 3 \\
\hline Shiekar & 2 & - & 1 & - & 5 \\
\hline Tikkin & 3 & - & - & 3 & 4 \\
\hline Sunsomil & - & - & 2 & 2 & 4 \\
\hline Pinglin & 3 & 2 & 1 & - & 6 \\
\hline Gung00 & - & 1 & - & 4 & 3 \\
\hline Puhoo & 3 & - & - & - & 5 \\
\hline
\end{tabular}

\section{Table.3 Morphological features of isolated genera of AM fungi}

\begin{tabular}{|c|c|c|c|c|c|}
\hline Genera & $\begin{array}{c}\text { Spore size } \\
(\mu \mathrm{m} \text { diameter })\end{array}$ & Spore shape & Spore colour & Spore wall & $\begin{array}{l}\text { Hyphal } \\
\text { colour }\end{array}$ \\
\hline Acaulospora & $115-170$ & $\begin{array}{l}\text { Globose to } \\
\text { sub globose }\end{array}$ & $\begin{array}{l}\text { Yellow brown to dark } \\
\text { brown }\end{array}$ & $\begin{array}{l}\text { Three layered } \\
\text { (L1.L2 and L3) }\end{array}$ & $\begin{array}{l}\text { Grey } \\
\text { white }\end{array}$ \\
\hline Gigaspora & $200-300$ & $\begin{array}{l}\text { Globose to } \\
\text { sub globose }\end{array}$ & $\begin{array}{l}\text { White to cream usually } \\
\text { a rose pink tint. }\end{array}$ & $\begin{array}{l}\text { Bilayered layered } \\
\text { (L1 and L2) }\end{array}$ & $\begin{array}{l}\text { Orange } \\
\text { brown }\end{array}$ \\
\hline Scutellospora & $100-170$ & $\begin{array}{l}\text { Sub globose } \\
\text { to ellipsoid } \\
\text { to oblong }\end{array}$ & $\begin{array}{l}\text { Cream to yellow or } \\
\text { pale orange brown to } \\
\text { dark orange brown }\end{array}$ & $\begin{array}{l}\text { Bilayered spore } \\
\text { wall (L1 and L2) }\end{array}$ & $\begin{array}{l}\text { Hyaline } \\
\text { to orange } \\
\text { white. }\end{array}$ \\
\hline Glomus & $40-120$ & $\begin{array}{l}\text { Globose to } \\
\text { ellipsoid }\end{array}$ & $\begin{array}{l}\text { red brown to almost } \\
\text { black most are yellow } \\
\text { brown }\end{array}$ & $\begin{array}{l}\text { three layered } \\
\text { (L1,L2 and L3) }\end{array}$ & $\begin{array}{l}\text { Hyaline } \\
\text { to } \\
\text { yellowish. }\end{array}$ \\
\hline
\end{tabular}




\begin{tabular}{|c|c|c|}
\hline Locations & Genera & Root colonization $(\%)$ \\
\hline Rajpora & $\begin{array}{l}\text { Gigaspora sp. } \\
\text { Glomus sp. }\end{array}$ & $\begin{array}{l}68.23 \\
72.05\end{array}$ \\
\hline Shadimarg & $\begin{array}{l}\text { Acaulospora sp. } \\
\text { Gigaspora sp. } \\
\text { Glomus sp. }\end{array}$ & $\begin{array}{l}65.87 \\
70.03 \\
72.13\end{array}$ \\
\hline Nikas & $\begin{array}{l}\text { Scutellospora sp. } \\
\text { Acaulospora sp. }\end{array}$ & $\begin{array}{l}69.09 \\
70.05\end{array}$ \\
\hline Drubgam & $\begin{array}{l}\text { Scutellospora sp. } \\
\text { Glomus sp. } \\
\text { Gigaspora } \mathrm{sp} .\end{array}$ & $\begin{array}{l}71.23 \\
76.67 \\
69.08\end{array}$ \\
\hline Shiekar & $\begin{array}{l}\text { Gigaspora sp. } \\
\text { Acaulospora sp. }\end{array}$ & $\begin{array}{l}73.56 \\
68.67\end{array}$ \\
\hline Tikkin & $\begin{array}{l}\text { Acaulospora sp. } \\
\text { Glomus sp. }\end{array}$ & $\begin{array}{l}72.13 \\
68.78\end{array}$ \\
\hline Sunsomil & $\begin{array}{l}\text { Gigaspora sp. } \\
\text { Glomus sp. }\end{array}$ & $\begin{array}{l}67.67 \\
79.55\end{array}$ \\
\hline Pinglin & $\begin{array}{l}\text { Acaulospora sp. } \\
\text { Gigaspora } \mathrm{sp} . \\
\text { Scutellospora } \mathrm{sp} .\end{array}$ & $\begin{array}{l}79.56 \\
67.80 \\
65.87\end{array}$ \\
\hline Gungoo & $\begin{array}{l}\text { Scutellospora sp. } \\
\text { Glomus sp. }\end{array}$ & $\begin{array}{l}69.77 \\
79.78\end{array}$ \\
\hline Puhoo & Acaulospora sp. & 76.86 \\
\hline
\end{tabular}

\section{Table.5 Chemical characteristics of soil samples of District Pulwama}

\begin{tabular}{|l|c|c|c|c|c|}
\hline Villages & $\begin{array}{c}\text { Or. } \\
\text { Carbon } \\
(\mathbf{\%})\end{array}$ & $\begin{array}{c}\text { Av. } \\
\text { Nitrogen } \\
\text { (kg/ha) }\end{array}$ & $\begin{array}{c}\text { Av. } \\
\text { Phosphorus } \\
\text { (kg/ha) }\end{array}$ & $\begin{array}{c}\text { Av. } \\
\text { Sulphur } \\
\text { (Kg/ha) }\end{array}$ & $\begin{array}{c}\text { Av. } \\
\text { Potassium } \\
\text { (kg/ha) }\end{array}$ \\
\hline Rajpura & 1.74 & 352.23 & 16.21 & 11.23 & 186.01 \\
\hline Shadimarg & 1.77 & 359.04 & 17.63 & 11.92 & 188.20 \\
\hline Nikas & 1.93 & 370.01 & 16.43 & 12.51 & 186.11 \\
\hline Drubgam & 1.79 & 365.34 & 17.34 & 12.01 & 188.23 \\
\hline Shiekar & 1.68 & 343.12 & 17.98 & 11.61 & 183.65 \\
\hline Tikkin & 1.83 & 360.05 & 17.23 & 12.13 & 188.06 \\
\hline Sunsomil & 1.74 & 351.23 & 17.01 & 11.61 & 180.13 \\
\hline Pinglin & 1.96 & 385.12 & 17.63 & 12.90 & 189.12 \\
\hline Gung00 & 1.82 & 358.07 & 17.60 & 12.02 & 188.14 \\
\hline Puhoo & 1.75 & 356.12 & 17.62 & 11.74 & 188.02 \\
\hline Mean & $\mathbf{1 . 8 0 1}$ & $\mathbf{3 6 0 . 0 3 3}$ & $\mathbf{1 7 . 2 6 8}$ & $\mathbf{1 1 . 9 6 8}$ & $\mathbf{1 8 6 . 5 6 7}$ \\
\hline CD $(\mathbf{p} \leq \mathbf{0 . 0 5 )}$ & $\mathbf{0 . 0 6 9}$ & $\mathbf{2 . 5 8 9}$ & $\mathbf{0 . 3 0 6}$ & $\mathbf{0 . 7 0 2}$ & $\mathbf{N S}$ \\
\hline CV & $\mathbf{2 . 2 2}$ & $\mathbf{8 . 4 1 6}$ & $\mathbf{1 . 0 2 5}$ & $\mathbf{3 . 4 2 8}$ & $\mathbf{1 . 6 7 9}$ \\
\hline
\end{tabular}


Table.6 Correlation between spore population and other studied parameters of District Pulwama

\begin{tabular}{|l|c|}
\hline Parameters & Spore population \\
\hline Spore population & 1 \\
\hline Organic carbon & $0.887 * *$ \\
\hline A vailable Nitrogen & $0.815^{*}$ \\
\hline A vailable Phosphorus & 0.797 \\
\hline A vailable Sulphur & 0.910 \\
\hline A vailable Potassium & $0.614^{*}$ \\
\hline Root colonization & $0.512 *$ \\
\hline$*$ Correlation is significant at the $\mathbf{0 . 0 5}$ level & \\
\hline **. Correlation is significant at the $\mathbf{0 . 0 1}$ level & \\
\hline
\end{tabular}

\section{Table.7 Correlation between available nutrients of representative} samples in District Pulwama

\begin{tabular}{|c|c|c|c|c|c|}
\hline Nutrients & $\begin{array}{l}\text { Organic } \\
\text { Carbon }\end{array}$ & $\begin{array}{l}\text { Available } \\
\text { Nitrogen }\end{array}$ & $\begin{array}{l}\text { Available } \\
\text { Phosphorus }\end{array}$ & $\begin{array}{l}\text { Available } \\
\text { Sulphur }\end{array}$ & $\begin{array}{l}\text { Available } \\
\text { Potassium }\end{array}$ \\
\hline Organic carbon & 1 & $0.931 * *$ & 0.514 & $0.923 * *$ & $0.784^{*}$ \\
\hline $\begin{array}{l}\text { Available } \\
\text { Nitrogen }\end{array}$ & $0.931 * *$ & 1 & 0.575 & $0.803 * *$ & 0.583 \\
\hline $\begin{array}{l}\text { Available } \\
\text { Phosphorus }\end{array}$ & 0.514 & 0.575 & 1 & 0.406 & 0.530 \\
\hline $\begin{array}{l}\text { Available } \\
\text { Sulphur }\end{array}$ & $0.923 * *$ & $0.803 * *$ & 0.406 & 1 & 0.493 \\
\hline $\begin{array}{l}\text { Available } \\
\text { Potassium } \\
\end{array}$ & $0.784 *$ & 0.583 & 0.530 & 0.493 & 1 \\
\hline \multicolumn{6}{|c|}{ *. Correlation is significant at the $\mathbf{0 . 0 5}$} \\
\hline
\end{tabular}

Study area

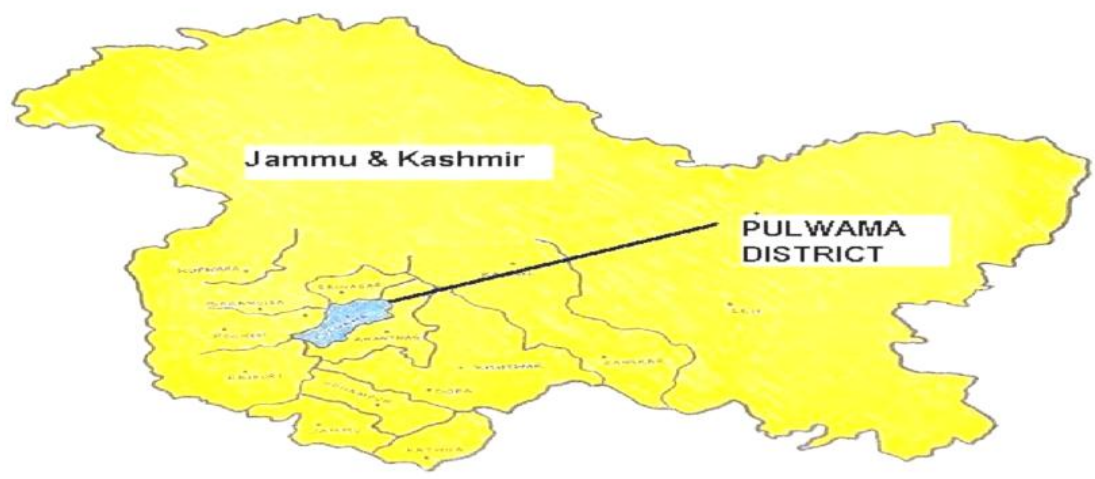


Fig.1 Spores of Acaulospora
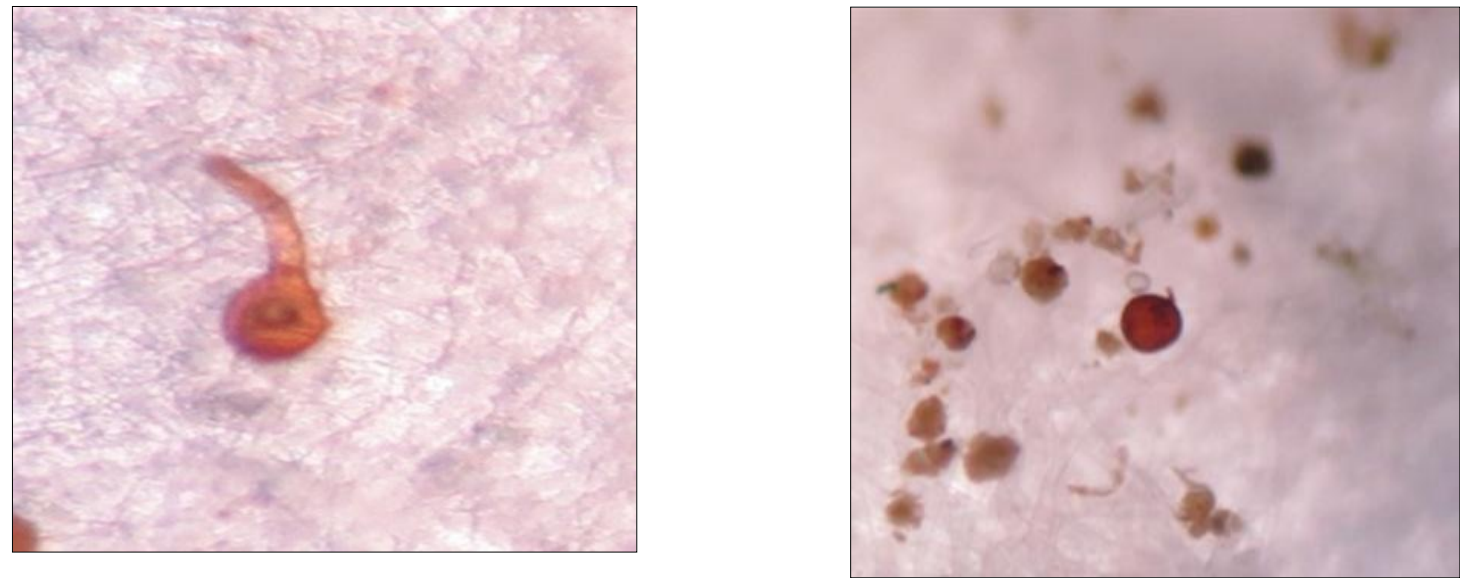

Fig.2 Spore of Glomus
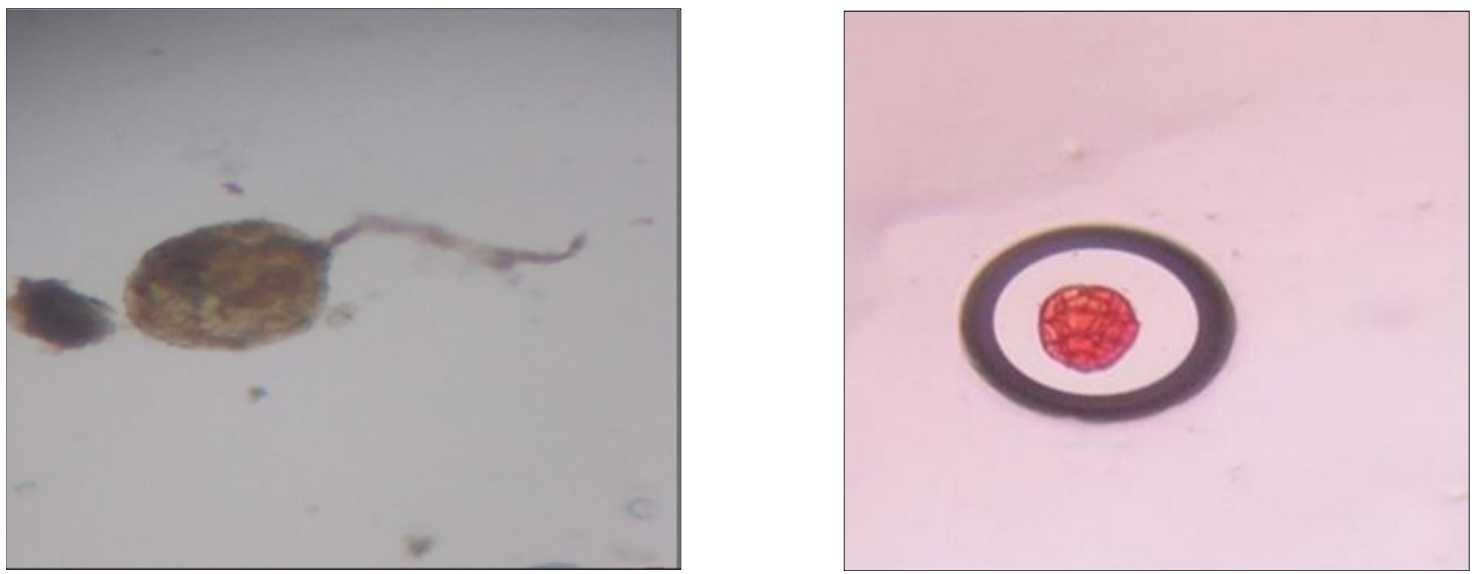

Fig.3 Spores of Gigaspora
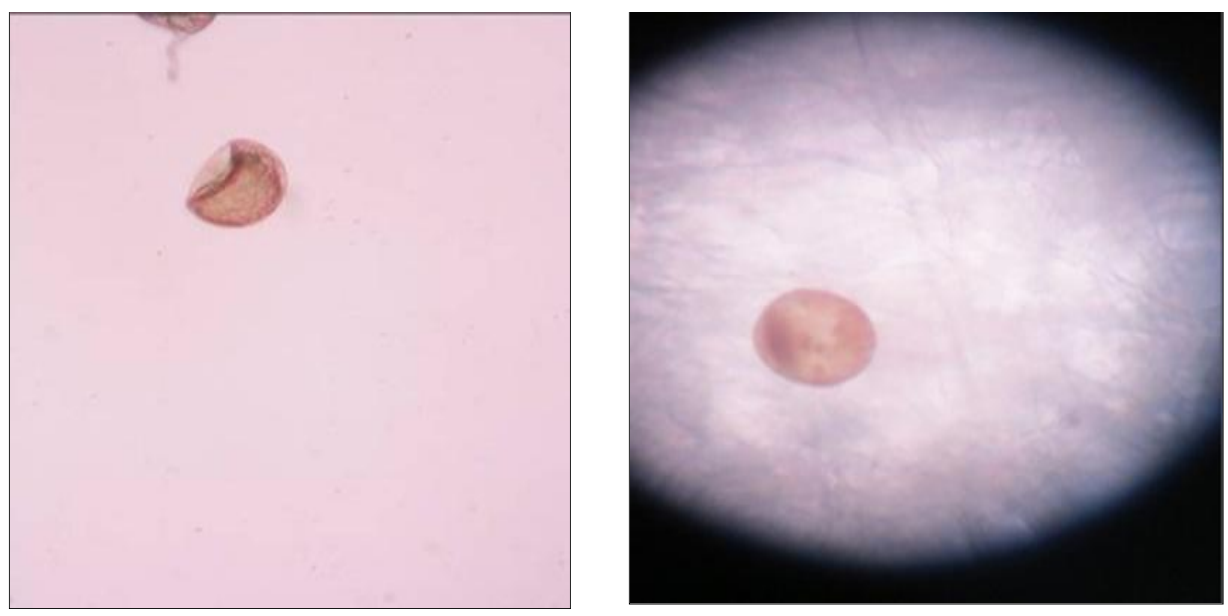
Fig.4 Spores of Scutellospora
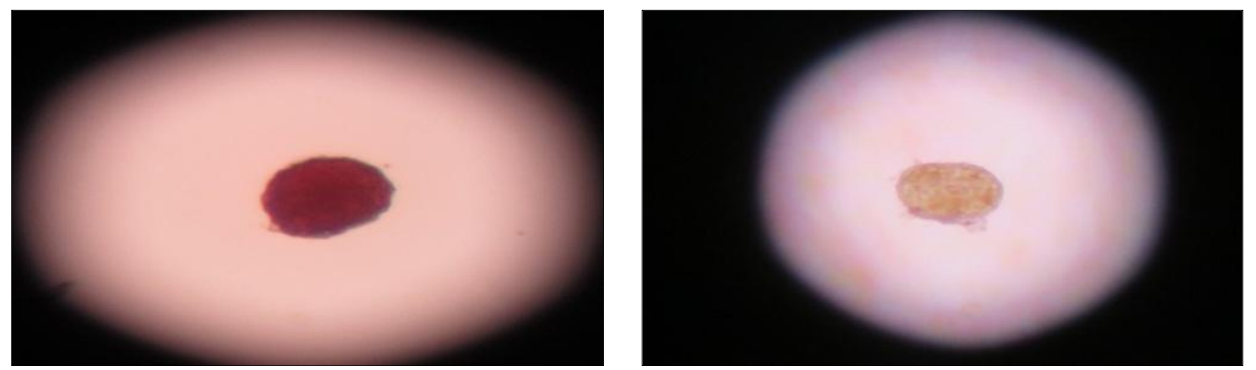

Fig.5 Root colonization of the genus Acaulospora
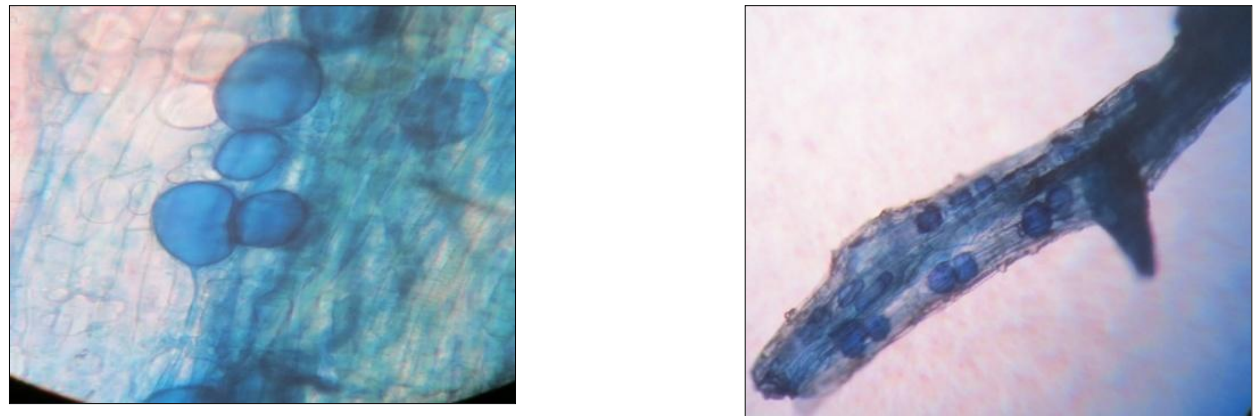

Fig.6 Root colonisation of the genus Scutellospora
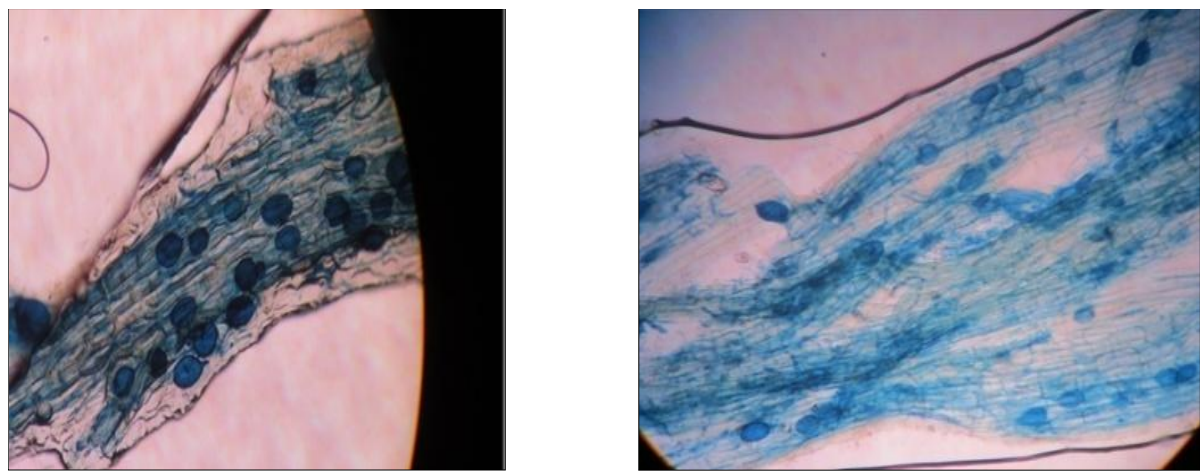

Fig.7 Root colonisation of the genus Glomus
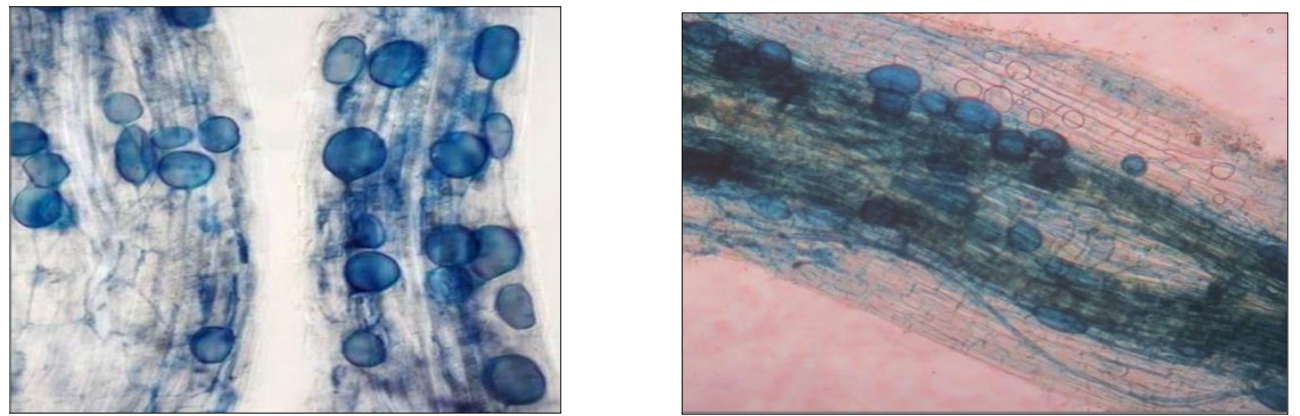
Fig.8 Root colonisation of the genus Gigaspora

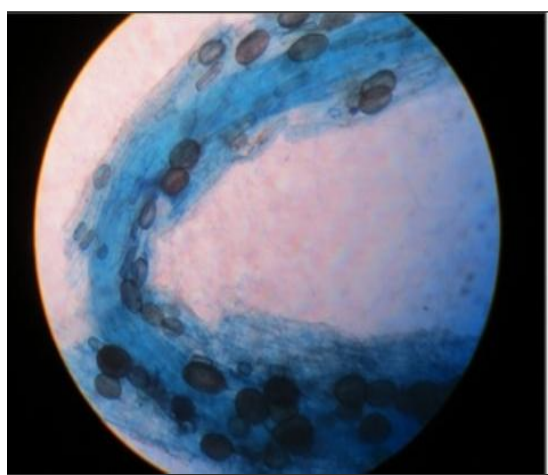

\section{Available nitrogen}

Available nitrogen content of the soils ranged from $343.12 \mathrm{~kg} \mathrm{ha}^{-1}$ (Shiekhar) and $385.12 \mathrm{~kg}$ $\mathrm{ha}^{-1}$ (Pinglin) with an average value of 360.03 $\mathrm{kg} \mathrm{ha}{ }^{-1}$. The available nitrogen content of Pinglin soil was significantly more than soils of other villages. However, available nitrogen of soils from Shadimarg and Gungoo were statistically at par. This is supported by the findings of Dar (1996). Najar (2002) also observed the available nitrogen content in the range of 200 to $350 \mathrm{~kg} / \mathrm{ha}$. Bhat (2001) while studying the apple orchard soils of north Kashmir also reported that, the available nitrogen content ranged from 300 to 410 $\mathrm{kg} / \mathrm{ha}$. Akhtar (2005) while working in the apple orchard soils of Kashmir valley also reported the available nitrogen content in the range of 320 to $410 \mathrm{~kg} / \mathrm{ha}$.

\section{Available phosphorus}

Available phosphorus content of soils ranged between $16.21 \mathrm{~kg} \mathrm{ha}^{-1}$ (Rajpura) and $17.98 \mathrm{~kg}$ ha $^{-1}$ (Shiekhar) with an average value of 17.26 $\mathrm{kg} \mathrm{ha}^{-1}$. The available phosphorus content of Shiekhar soil was significantly more than soils of other villages except Shadimarg and Pinglin which were statistically at par. Khan et al., (2013) reported that the available phosphorus was in the range of 10 to 24 $\mathrm{kg} / \mathrm{ha}$. The high available phosphorus may be due to application of organic manures like

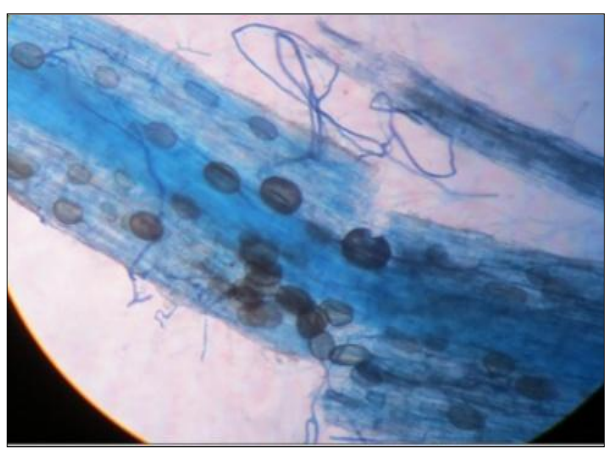

FYM, vermicompost and biofertlizer. These findings are supported by Kumar et al., (2009).

\section{Available potassium}

Available potassium content of soils ranged between $180.13 \mathrm{~kg} \mathrm{ha}$ (Sunsomil) and $189.12 \mathrm{~kg} \mathrm{ha}^{-1}$ (Pinglin) with a mean value of $186.56 \mathrm{~kg} \mathrm{ha}^{-1}$. This is supported by the findings of Aon and Colaneri (2001) who also observed the potassium in range of 178.67 to $197.12 \mathrm{~kg} / \mathrm{ha}$ in the apple orchard soils of Himachal Pradesh.

\section{Correlation studies}

Table 6 revealed that correlation of AM spore population with organic $\mathrm{C}\left(\mathrm{r}=0.887^{* *}\right)$, available $\mathrm{N} \quad\left(\mathrm{r}=0.815^{*}\right)$, available $\mathrm{K}$ $\left(\mathrm{r}=0.614^{*}\right)$ and root colonization $\left(\mathrm{r}=0.512^{*}\right)$ were found to be positive and significant in District. However positive, but nonsignificant correlation was observed with respect to available $P$. The results are in conformity with those of Lipinski et al., (2003) who also reported a significant positive correlation between soil organic carbon and AM spore population. The positive and significant correlation between AM spores and available nitrogen $\left(r=0.815^{*}\right)$ was found which might be due to the fact that nitrogen and organic carbon are required by micro-organisms for their special 
requirements and as a result high nitrogen and organic carbon in the soil increased infection and population of AM fungi. Similar results were reported by Venkatrao et al., (1972).

\section{Between available nutrients of representative samples of District Pulwama}

Perusal of the data present in Table 7 reveals that the organic carbon content of soils of representative villages was found to be positively and significantly correlated with available nitrogen $\left(\mathrm{r}=0.931^{* *}\right)$, available sulphur $\left(\mathrm{r}=0.923^{* *}\right)$ and available potassium $(\mathrm{r}=0.784 *)$ but correlation was positive and non-significant with available phosphorus.

The available nitrogen content of soils was positively and significantly correlated with organic carbon and available $\mathrm{S}$ while as positive and non-significant correlation was observed with available $\mathrm{P}$ and $\mathrm{K}$. The available phosphorus content of soils was positive and non-significantly correlated with Organic C, available N, S and K contents. The available sulphur from soils was found to be positively and significantly correlated with organic carbon $\left(\mathrm{r}=0.923^{* *}\right)$, available $\mathrm{N}$ $\left(\mathrm{r}=0.803^{* *}\right)$ while as positive and nonsignificant correlation was recorded with Available $\mathrm{P}$ and $\mathrm{K}$. The available potassium was found to be positively and nonsignificantly correlated with available $\mathrm{N}, \mathrm{P}$ and $\mathrm{S}$ from the soils. However, the correlation with organic carbon $\left(\mathrm{r}=0.784^{*}\right)$ was positive and significant.

\section{Acknowledgement}

The authors are thankful to Sher e Kashmir University of Agricultural Sciences and Technology of Kashmir for providing laboratory facilities for carrying out this research work. The help rendered by orchardists during field surveys are highly put on record.

\section{References}

Akhter, F. 2005. Studies on relationship between fruit yield and quality with soil and leaf nutrient content in apple orchards of Zangier block of district Baramulla Kashmir. University of Kashmir Digital Repository

Almeida, R. T and Schenck, N. C. 1990. A revision of the genus Sclerocystis (Glomaceae, Glomales) Mycologia 82: 703-714.

Aon, M. A. and Colaneri, A. C. 2001. Temporal and spatial evolution of enzymatic activities and physicochemical properties in an agricultural soil. Applied Soil Ecology 18(3):255270.

Beckjord, P. R., McIntosh, M. S., Hacskaylo, E. and Melhuish, J. H. 1984. Inoculation of Loblolly Pine Seedlings at Planting with Basidiospores of Ectomycorrhizal Fungi in Chip Form. Research Note No. 324, Forest Service, North-Eastern Forest Experiment Station, Florida, USA: 25.

Bentivenga, S. P. and Morton, J. B. 1995. A monograph of the genus Gigaspora, incorporating developmental patterns of morphological characters. Mycologia 87:720-732.

Bhat, M. S. 2001. Nutritional status high density plantation of apple orchards soils of North Kashmir. M Sc. Thesis submitted to SKUAST-K Srinagar: 1375

Bulluck, L. R., Brosius, M., Evanylo, G. K. and Ristaino, J. B. 2002. Organic and synthetic fertility amendments influence soil microbial, physical and chemical properties on organic and commercial farms. Applied Soil Ecology 19: 147160.

Burni, T., Iftikhar, S., Jabeen, M. Zainab, S.B. 2009. Diversity of VA (Vesicular Arbuscular) fungi in some weeds of 
cauliflower fields of Peshawar, Pakistan. Pak. J. Plant Sci. 15(1): 5967.

Chesnin, L. and Yien, C. H. 1951. Turbidimetric determination of available sulphur. Proc. Soil Sci. Soc. Am. 15: 149-151.

Dar, M.A. 1996. Nutrient status of cherry (Prunus avium L.) orchards of Srinagar district. M.Sc. Thesis submitted to SKUAST-Kashmir Srinagar: 1-140.

Gerdemann, J. W., Nicolson, T. W. 1963. Spores of mycorrhizal Endogone species extracted from soil by wet sieving and decanting method. Trans. Br. Mycol. Soc. 46: 235-245.

Giovannetti, M and Mosse, B. 1980. An evaluation of techniques for measuring vesicular Arbuscular mycorrhizal infection in roots. New Phytol. 84:489509.

Gomez, K. A and Gomez, A. A. 1984. Statistical procedure for Agricultural Research An international Rice Research Institute Book. John Wiley and sons, 2nd edition 190.

Gosal, S. K., Sandhu, A., Gupta, R. P and Kaul, V. K. 2003.Establishment and maintenance of vesicular arbuscular mycorrhiza on hode grass. Indian Journal of Microbiology. 43(1): 53-54.

Greene, D. W., Manning, W. J., Cooley, D. R. 1982. Effect of the ectomycorrhizal fungus Pisolithus tinctorius and auxin rooting formulations on growth of 'Cortland' apple trees. Hortic. Sci. 17: 655- 656

Hayman, D. S. 1982. The physiology of vesicular arbuscular endo-mycorrhizal symbiosis. Canadian Journal of Botany 61: 944-963.

INVAM website. http://invam.caf.wvu.Edu/ fungi/taxonomy/classification.html.2005

Jackson, M.L.1973. Soil Chemical Analysis. Prentice Hall India, New Delhi, India. 498.
Kandula, K., Jones, Stewart, A and Horner, J. 2006. Colonisaton of apple roots by arbuscular mycorrhiza in specific apple replant disease affected soil. New Zealand Plant Prot. 59:92-96.

Khan, M. S., Ahmad, E., Zaidi, A and Oves, M. 2013. Functional aspect of phosphate-solubilizing bacteria: importance in crop production. Bacteria in Agrobiology: Crop Productivity pp. 237-263

Koske, R.E., Gemma, J.N.1990.VA mycorrhizae in strand vegetation of Hawaii: evidence for long-distance codispersal of plants and fungi. Am. J. Bot.77:466-474.

Koske, R.E.1984 Spores of VAM fungi inside spores of VAM fungi. Mycologia. 76:853-862

Koske, R.E.1987. Distribution of VA mycorrhizal fungi along a latitudinal temperature gradient. Mycologia. 79:55-68.

Kumar, R. P., Singh, Y., Dwivedi, S and Singh, J. P. 2009. Effect of integrated nutrient management on growth, yield, nutrient uptake and economics of French bean (Phaseolus vulgaris). Indian Journal of Agricultural Science 79 (2): 122-128.

Kumar, S., Chaudhuri, S and Maiti, S.K. 2013.Soil dehydrogenase enzyme activity, in Natural and mine soil - a review. Middle-East J. Sci. Res.2013. 13(7): 898-906

Li, L., Li, T., Zhang, Y and Zhao, Z. 2009. Molecular diversity of Arbuscular mycorrhizal fungi and their distribution patterns related to host-plants and habitats in a hot and arid ecosystem, southwest China. FEMS Microbiol. Ecol. 71: 418-427.

Lipinski, W., Terelak, $\mathrm{H}$ and Motowicka, T. 2003. Suggestion for liming values of sulphate, sulphur content in mineral 
soils for fertilization advisory needs. Soil Sci. Annu.2003. 54(3): 79-84.

Morton, J.B and Benny, G.L.1990. Revised classification of Arbuscular mycorrhizal fungi (Zygomycetes): a new order, Glomales, two new suborders, Glomineae and Gigasporineae, and two new families, Acaulosporaceae and Gigasporaceae, with an emendation of Glomaceae. Mycotaxon. 37: 471-491

Morton, J.B.2002. International Culture Collection of Arbuscular and VesicularArbuscular mycorrhizal Fungi. West Virginia University.2002.

Mosse, B. 1973. Fructification of an Endogone species causing endotrophic mycorrhiza in fruit plants. Annuals of Botany 20: 349-362.

Mridha, M and Dhar, P. 2007. Biodiversity of Arbuscular mycorrhizal colonization and spore population in different Agroforestry trees and crop species growing in Dianajpur Bangladesh. J. Forest. Res. 18(2): 91-96.

Najar, G. R. 2002. Studies on pedogenesis and nutrient indexing of apple (Red Delicious) growing soils of Kashmir Thesis submitted to SKUAST-Kashmir, Srinagar: 1-204.

Olsen, S.R., Cole, C.V., Watanabe, F.S and Dean LA.1954. Estimation of available phosphorus in soils by extraction with sodium bicarbonate. U.S. Dept. Agric. Circ.939.

Pande, M and Tarafdar, J.F. 2004. Arbuscular mycorrhizal fungal diversity in Neem based Agroforestry Systems in Rajistan. Appl. Soil Ecol.26:233-241.

Phillips, J.M and Hayman, D.S. 1970. Improved procedures for clearing roots and staining parasitic and vesicular Arbuscular mycorrhizal fungi for rapid assessment of infection. Trans. Br. Mycol. Soc.55:150-161.

Schenck, N.C and Parez, Y. 1990. Manual for the identification of VA mycorrhizal fungi INVAM, University of Florida, Gainesville USA. Pp. 1-283.

Sharma, D., Kapoor, R and Bhaytnagar, A.R. 2009. Differential growth response of Curculigoorchoides to native AMF communities varying in number and fungal components. Euro. J. Soil Biol. 45(4): 328-333.

Smith, S.E and Read, D.J. 2008. Mycorrhizal Symbioses. Academic Press, London, U.K. Assessment of Mycorrhizal Frequency in the Roots of Fruit Plants Using Different Dyes.

Stanford, S and English.1949. Use of the flame photometer in rapid soil tests of potassium and calcium. Agron. J. 41:446-447.

Subbiah, B. V. and Asija, G. L. 1956. A rapid procedure for estimation of available nitrogen in soils. Current Science 25: 259-260.

Venkatrao, B.V., Bagyaraj, D.J and Rangaswamy, M. 1972. Changes in physiological and microbial properties of red soils of Mysore as a result of heavy fertilization. Indian J. Agric. Sci. 42: $226-29$.

Walker, C and Vestberg, M.1998. Synonymy amongst the Arbuscular mycorrhizal fungi: Glomus claroideum, $G$. maculosum, G. multisubstensum, and $G$. fistulosum. Annals of Botany.82: 601612.

Walker, C., Vestberg, M., Demircik, F., Stockinger, H., Saito, M., Nishmura, I and Schubler A.2007.Molecular phylogeny and new taxa in the Archaesporales (Gloremycota): Ambiospora feennicagen sp. nov., Ambisporaceae fam nov., and emendation of archaeospora and Archaesporaceae. Mycol. Res.111:137153.

Walkledy, A and Black, I.A.1934. An examination of the Degtjareff method for determining soil organic matter and 
a proposed modification of the chromic acid titration method. Soil Sci. 37:2938.

Wani, M. A., Mushtaq, Z. and Nazir, S. 2010. Mapping of micronutrients of the submerged rice soils of Kashmir. Research Journal of Agricultural Science 1(4): 458-462
Yang, R.Y., Zan, S.T., Tang, J.J., Chen, X and Zhang, Q. 2010.Variation in community structure of Arbuscular mycorrhizal fungi associated with a $\mathrm{Cu}$ tolerant plant- Elsholtzia splendens. Appl. Soil Ecol. 44:191-197.

\section{How to cite this article:}

Misbah Ajaz Malik, M.Y. Zargar, Masrat Maqbool, Bisma Rashid, Z.A Baba and Malik Asif. 2018. Effect of Arbuscular Mycorrhizal Fungi on Soil Chemical Characteristics in Apple Orchards of Kashmir Himalaya. Int.J.Curr.Microbiol.App.Sci. 7(06): 314-327. doi: https://doi.org/10.20546/ijcmas.2018.706.036 